Zhang, Z \& Liu, X. (2020). Control and Uncertainty: Towards a Paradigm of Prototyping. Landscape Architecture Frontiers, 8(4), 10-25. https://doi. org/10.15302/J-LAF-1-020032

\title{
控制与不确定性: 对原型思维范式的展望 CONTROL AND UNCERTAINTY: TOWARDS A PARADIGM OF PROTOTYPING
}

\section{1 引言：模型、控制与不确定性}

“景观的非人类属性及其文化构建之间，以及人类对自然的敬畏 和对其进行利用、管理与控制的冲动之间，总是存在着矛盾。” ${ }^{1}$ 景 观设计师在对生命系统和物质进行设计时, 经常会遇到意料之外的情 况。那么，原型概念将如何帮助设计师应对设计中的不确定性?
弗吉尼亚大学建筑学院构建环境博士候选人、景观系讲师

刘浔

弗吉尼亚大学建筑学院构建环境博士研究生、景观系教师

摘要

本文探索了一种不同于模型设计的原型思维 新范式。在将控制论与景观设计进行并置分析后 发现，自20世纪至21世纪初，景观设计学科的发 展规律反映了控制论在同一时期的发展进程。早 期关于系统动力学的决定论和线性理解, 逐渐被 基于演生论和开放式的主张所取代。在演生论的 框架下，笔者强调一类可被理解为原型的特殊模 型不能被基于 “建模 - 预测 - 控制” 的传统框 架所包容。原型并不像传统建模过程那样, 用 模型代表一个开放的生命系统，原型本身就可 以被理解为一个独立的生命体系。原型思维可以 取代模型设计, 并展现出三方面的特质: 1) 原型 本身即具有 “生命力” , 这是设计与创造力的根 本；2 ) 原型的真正意义在于其未被定义的状态, 而不在于其可被定义的最直接的用途；3）这种未 被定义的状态能够提供无限可能, 并将人们与未 来之间的关系从过去的偶然性和预测转变为期 待与展望。

关键词

原型；景观；控制论；系统思维；不确定性；控制

编辑 田晓劼 翻译 张书瑞 张子豪 刘浸 田晓咭

EDITED BY TIAN Xiaojie tRANSLATEd BY ZHANG Shurui ZHANG Zihao LIU Xun TIAN Xiaojie

\section{ZHANG Zihao*}

PhD Candidate in Constructed Environment and Lecturer in Landscape Architecture, School of Architecture, University of Virginia

LIU Xun

PhD Student in Constructed Environment and Teaching Fellow in Landscape Architecture, School of Architecture, University of Virginia

\section{*Corresponding Author}

Address: Campbell Hall, School of Architecture, 110 Bayly D Charlottesville, VA 22903, USA Email: zz3ub@virginia.edu

\section{ABSTRACT}

This paper maps out a new paradigm of prototyping that acts as an alternative to the model-making paradigm. By juxtaposing the cybernetics movement with landscape design, the authors have mapped out a development in landscape discourse that mirrors the movement of cybernetics in the 20 th century and early 21 st century. The early deterministic and linear understanding of systems dynamics is replaced by an emergent and openended view. Taking on a framework of emergence, the authors highlight a special type of model that does not fit within the conventional modelpredict-control framework. Rather than models that represent another living system, these models are living systems in themselves with autonomy and lives. This special type of model can be understood as prototypes. Prototyping replaces model-making and exhibits three distinctive qualities: 1) A prototype has a life of its own, which serves as the basis for design and creativity; 2) The real usefulness of a prototype lies in its undefined identity rather than its defined and direct application; And 3) the identified quality provides a wide range of possibilities, thus changing our relationship with the future from chance and prediction to anticipation and hope.

\section{KEYWORDS}

Prototype; Landscape; Cybernetics; Systems

Thinking; Uncertainty; Control 
牛津英语词典将 “原型”（prototype ) 定义为 “人或事物的第一 个或主要类型; 基于此本源可以模拟或衍生出其他事物; 是一种典范 （ exemplar）或初型（archetype）” [2]。原型一词首先被普遍使用于工 业设计和软件工程中，用来指代以概念测试为目的的第一台机器或第 一个程序。原型概念具有双重属性：一方面，它是一种表明某一事物 与另一事物之间存在着隐喻关系的模型; 另一方面, 原型还具有一种 超越隐喻的真实感。原型的双重属性使其成为一种特殊的模型，通过 它可以反思控制与不确定性之间的矛盾。

然而, 由于西方文化中根深蒂固的 “手段一目的链” 思维方式 (即以手段达到目的), 原型理论在历史上被长期忽视。在西方哲学 传统中, 人们往往用一种理想形态 (eidos) 作为模型, 并将其设为目 标 (telos) 采取行动。正如法国哲学家弗朗索瓦・朱利安所说, “我 们 (西方人) 将目光集中在构想出的模型上, 并将其投射在现实世界 中, 以此来指导我们的行动; 从这个意义上讲, 我们选择去干预周遭 世界并赋予现实以形式。” ${ }^{[3]}$ 这种思考模式将理论与实践区分开来: 理 论成为模型的基础, 而实践则成为将模型变为现实的一系列行动。最 重要的是, 行动是否有效以及可否被测量, 也受到这种思维习惯的深 刻影响：人们习惯于评价工具和措施的功效性。由此可见，功效性决 定了手段一目的链的思维逻辑。最后, 尽管人们想把一个理想的模型 投射在周遭世界中, 并试图研究出各种方法来实现这一模型, 但过程 中总会出现无法预测的情况, 影响计划的控制和实施。因此, 所谓不 确定性是指那些在构想出的模型中无法预测的状况 ${ }^{[3]}$ 。

在当代的环境实践中，手段一目的链体现在方方面面。例如， 在过去几年间，环境实践中出现了新一轮对建模的讨论。包括智慧城 市在内的许多研究都提出要把传感网络融人环境中, 从而产出更多数

\section{Introduction: Model, Control, and Uncertainty}

"There is always a tension in landscape between the reality and autonomy of the nonhuman and its cultural construction, between the human impulse to wonder at the wild and the compulsion to use, manage, and control." ${ }^{[1]}$ Designing with living systems and materials, landscape designers always have to deal with unexpected outcomes. What insights can the idea of prototype provide to address the issue of uncertainty?

Oxford English Dictionary defines the term of "prototype" as " $[\mathrm{t}]$ he first or primary type of a person or thing; an original on which something is modeled or from which it is derived; an exemplar, an archetype" ${ }^{[2]}$. The term was first popularized in industrial design and software engineering to denote the first machine or the first piece of program that was built to prove the concept. A prototype possesses a twofold quality: On the one hand, a prototype is a type of model, which has a kind of metaphorical relationship between one thing and another; On the other hand, a prototype also carries a sense of realism that is beyond a metaphor. This twofold quality makes prototype a special type of model that can transform people's understanding of the tension between control and uncertainty.

However, rooted in the western means-end chain relationship, prototypes have always been overlooked theoretically and historically. In the western philosophical tradition, one envisages an ideal form (eidos) as a model, and then the model can serve as a goal (telos) and, at the same time, an end that calls for actions. As French Philosopher Francois Jullien puts forward that "with our eyes fixed on the model that we have conceived, which we project on the world and on which we base a plan to be executed, we choose to intervene in the world and give a form to reality." [3] Based on this line of reasoning, theory can be differentiated from practice, the former being the basis for the model, and the latter being a set of operations that make the model turn into reality. Most importantly, with the means-end relationship, the idea of effectiveness and measure can be tied into this habitual reasoning. Once a range of possible tools and actions are at hand, their effectiveness will be evaluated. Efficacy becomes the concept that ties the "means" and the "end" together. Finally, although people want to project an ideal model on the world and develop means to achieve this end, unexpected circumstances will always rise to undermine the action and control regime of any plan. Thus uncertainty denotes those events that are outside the predictions allowed by the conceived model ${ }^{[3]}$.

This means-end chain can be observed in every aspect of contemporary environmental practices. For example, the past few years have seen a new round of model-making in the 
据, 机器学习 (ML) 算法便能利用这些数据来构建人工智能 (AI) 系 统, 随后将AI系统 (即模型) 应用于信息物理系统之中, 以管理各种 环境过程 (如雨洪控制 ${ }^{[4]}$ ) 。但是, 这一建模框架受困于手段一目的链 思维方式, 因为在手段一目的链中, 不确定性只被理解为模型与环境 间必须要被消除的差异, 而这种控制和不确定性间的矛盾只会一直横 亘在人们与未来的关系之间。

在过去几十年间, 景观理论与实践不断挑战着手段一目的链以及 模型在环境设计实践中的作用 ${ }^{[5]}$ 。这些景观实践强调了原型作为一种特 殊模型的价值, 而这种价值并不能用手段一目的链思维方式来解释。 本文以景观实践为例, 阐明原型在环境设计中的价值, 即原型提供了 一种新的方式来思考建模过程：建模不是为了消除不确定性，而在于 探索更广泛的可能性。如此一来，人们与未来的关系也不再受困于控 制与不确定性之间的矛盾, 而是转变为一种期待与展望, 这对于人类 应对气候变化等诸多环境挑战而言至关重要。

鉴于模型和控制与不确定性之间的矛盾是控制论和系统论的核心 议题, 因此, 在控制论和系统思维的发展过程中, 重新研究如何诠释 原型也就变得尤为重要。如将一系列景观作品和控制论的三次思潮进 行对照，会发现早期控制论中的手段一目的链并不适用于当代系统性 的景观设计; 相反, 景观设计可以为原型思维提供不同见解。

对原型的新的认知能够帮助解析控制论运动中的原型思维概念, 并发掘了包括诺伯特 - 维纳的 “蛾” 和 “臭虫”, 以及约翰 - 冯 - 诺 伊曼的细胞自动机在内的一系列 “反馈生物” (1)。受手段一目的链思维 方式的影响, 这些可以作为控制论运动原型的反馈生物一直为人所忽 视。基于此, 这些控制论原型可与一个景观学科的案例一一哈佛大学 设计研究生院 (GSD) 的响应式环境及人工产品实验室 ( REAL) 进行 environmental discourse. Myriad of research initiatives, such as smart cities, propose to embed sensing networks in the environment to produce more data. Then, the environmental data feeds into Machine Learning (ML) algorithms to build Artificial Intelligence (AI) systems. Finally, these AI systems, or models, are distributed in the cyberphysical systems to manage all kinds of environmental processes, such as stormwater control $^{[4]}$. However, trapped in a means-end relationship, this framework only conceptualizes uncertainty as modelenvironment difference that needs to be reduced one way or another. In the means-end chain, human's relationship with the future always revolves around the tension between control and uncertainty.

Landscape theory and practice in the past decades have provided a body of work that challenges the means-end chain and the role of models in environmental practices ${ }^{[5]}$. These practices highlight the value of prototypes as a special type of model that does not fit within the means-end chain. This paper uses landscape practices to articulate the values of prototypes in the environmental discourse, and argues that with prototypes, model-making can be envisaged in such a way that is no longer on the line of reducing uncertainty but about providing a wide range of possibilities. Thus, our relationship with the future is transformed from the tension between control and uncertainty to anticipation and hope, which is crucial when humanities are faced with environmental challenges such as climate change.

Since the idea of model and the tension between control and uncertainty have always been central to the field of cybernetics and systems theory, it is crucial to re-examine how the idea of prototype was articulated in the development of cybernetics and systems thinking. Contrasting a body of landscape works and the three waves of cybernetics movement shows that the contemporary system-based landscape design framework does not fit within the means-end that is entailed by early cybernetic principles; Instead, landscape design can provide an alternative understanding of model-making on the line of prototyping.

This updated understanding can help parse out the concept of prototyping in the cybernetics movement and unearth a family of "cybernetic creatures," i including Norbert Wiener's "the moth" and "the bedbug," and John von Neumann's cellular automaton, as prototypes in the cybernetics movement which has been overlooked within the means-end chain. These cybernetic prototypes can be juxtaposed with a case study in landscape design - a hydromorphology table experiment conducted at the Responsive Environments \& Artifacts Lab
(1) Cybernetics研究的是 动物和机器之间的控制 与反馈机制，而控制只 与反债机制，而控制只 是其应用领域, 单纯将 cybernetics 译为 “控 制论” 并不准确且易造 成歧义, 因此本文将 cybernetic creatures和 cybernetic machine中 的cybernetic译为 “反 馈”。

Cybernetics studies the control and feedback mechanism between animals and machines, and control is only its application field. It is not accurate and easy to cause ambiguity to simply translate to simply translate 论". Therefore, this pape translates cybernetic into "反馈" when it refers to cybernetic creatures and cybernetic machines. 
的水文地貌沙床实验——进行并置分析。这一案例可以帮助总结出原 型的三个特征，以重新理解环境实践中的不确定性。

\section{2 背景：控制论与景观设计}

控制论是自20世纪40年代以来在美国发展出的一个交叉学科研究 领域。第二次世界大战后, 包括工程师、数学家、人类学家和生态学 家等在内的知识分子基于系统思维的新理论框架对机械系统和生物系 统间的相互控制与交流进行了研究。控制论的核心焦点是如何通过反 馈机制控制不同的系统, 以减少不确定性。直到近几年, 学者们才开 始关注控制论原理对景观设计的影响 ${ }^{[6 \mid 17]}$ 。有学者认为, 某些控制论理 念是在 20 世纪 60 年代通过生态科学和艺术等学科渗透到景观设计学科 中来的。伊恩 - 麦克哈格和劳伦斯 - 哈普林是在控制论与景观设计之 间建立联系的两位关键性人物 ${ }^{[7]}$ 。但由于控制论的交叉学科属性, 系 统论思想早已盛行于各学科, 因此控制论中的概念也早在 20 世纪便已 经对学界产生了广泛影响。控制论最初提出的诸多概念 (如反馈、耦 合、自生系统论）已被纳人社会学、计算机科学、系统理论、生态学 和人文学科, 而这些学科都是景观设计师汲取灵感的土壤。因此, 可 以说自 20 世纪 60 年代以来, 控制论以及控制与不确定性等议题已广为 人知。本文通过介绍 20 世纪中叶以来控制论与景观设计理论和实践各 自的发展历程, 将重点论述原型思维对景观设计理论和实践的影响, 从而帮助景观设计师重新思考不确定性这一议题。

凯瑟琳・海尔斯将控制论的发展概括为三次发生于不同学科领域 的思潮 ${ }^{[8]}$ 。第一次思潮（通常也被称为一阶控制论）是指1946 1953 年间召开的关于控制论的 “梅西会议” 以及此后 20 年间的相关研究。 维纳和冯 - 诺伊曼等早期控制论学者致力于研究稳态系统的反馈机制 和控制策略。第一次思潮后期, 包括玛格丽特 - 米德、格里高里 - 贝 特森和海因茨 - 冯 - 福斯特等在内的人类学家和哲学家, 开始对工程 师在建模过程中扮演的观察者身份提出质疑, 并提出二阶控制论的新
(REAL) of Harvard Graduate School of Design (GSD). With the cases, the case study can help map out three characteristics of prototypes that provide an alternative understanding of uncertainty in environmental practices.

\section{Background: Cybernetics and Landscape Design}

Cybernetics is an interdisciplinary field of study that started in the United States since the 1940s, when a team of post-war intellectuals, including engineers, mathematicians, anthropologists, and ecologists, converged on a new theoretical model based on systems thinking to understand control and communication between mechanical and biological systems. The core concern in the field is about how to control different systems through feedback mechanisms to mitigate uncertainty. It is only in recent years that scholars have started to pay attention to the influence of cybernetics principles on landscape design ${ }^{[6][]}$. It is argued that cybernetics concepts instilled into the landscape discipline via ecological sciences and arts in the 1960s, and Ian $\mathrm{McHarg}$ and Lawrence Halprin were two prominent figures who established the link between cybernetics and landscape design ${ }^{[7]}$. However, because of the interdisciplinary nature of cybernetics, its concepts were instilled in every aspect of intellectual life in the 20th century as systems theory has prevailed across disciplines. Many ideas such as feedback, coupling, and autopoiesis that were initially developed in the field of cybernetics have been imported into disciplines such as Sociology, Computer Science, Systems Theory, Ecology, and Humanities, all of which are fields where landscape architects have been drawing inspirations. Thus, it can be simply recognized that, since the 1960s, cybernetics and the issue of control and uncertainty have been "in the air." This paper contrasts the cybernetics movement with landscape design theory and practice since the mid-20th century and highlights the idea of prototyping in both fields that help landscape architects rethink the issue of uncertainty.

Katherine Hayles schematized the development of cybernetics as three waves of research mobilizing among different fields of study ${ }^{[8]}$. The first wave of research, commonly known as first-order cybernetics, speaks to the Macy Conferences on cybernetics from 1946 to 1953 and the research in the following two decades. Early cyberneticians such as Wiener and von Neumann focused on the feedback mechanism and control strategies in homeostatic systems. Towards the end of the first wave of research, anthropologists and philosophers including Margret Mead, Gregory Bateson, and Heinz von Foerster problematized the role of engineers as observers in the model-making process, trying to propose a new framework, 
框架一一这一框架将观察者作为反馈系统的一部分 ( 图1)。这种观念 上的转变引发了 20 世纪60年代后期至70年代的第二次研究思潮。这期 间, 学者们致力于探寻观察者在建模过程中的作用, 其中智利生物学 家温贝托 - 曼图拉那和弗朗西斯科 - 瓦雷拉提出了 “自生系统论” , 以阐释系统如何利用物质和信息流维持自身属性 ${ }^{[9]}$ 。之后, 瓦雷拉开始 涉足人工生命领域, 并引发了于 20 世纪 90 年代初期兴起的第三次控制 论思潮, 其中的焦点议题是演生论与复杂性。通过人工生命实验这种 多智能体模拟, 学者们认为诸如 “智能” 和 “意识” 之类的复杂现象 实际上可以被理解为分布式系统之间相互作用的结果。自 20 世纪 90 年 代后期以来, 第三次思潮开始不断挑战人类例外论, 并引发了一系列 后人类主义的思考 ${ }^{[8]}$ 。

控制论的三次思潮的研究焦点可以与景观研究和实践进行比照 （图2）。麦克哈格的生态学设计方法对于景观的控制可以视为一阶控 制论的一种体现。工程师们通常通过控制熵来维持一个机械系统的稳 态; 在热力学中, 熵是指系统向着无序状态发展的趋势; 麦克哈格在 其著作中大量使用熵的概念, 并将其与生态适应性进行类比。在他看 来, 熵即不确定性, 会对生态系统的完整性造成威胁。因此, 他认为 景观设计师应遵循理想的生态演替模型来控制景观变化, 最终达到生 态系统 “演替顶级” 的平衡状态 ${ }^{[7]}$ 。然而, 当代景观理论和实践注重开 放性与演生, 而麦克哈格设计框架中的环境决定论和对于生态过程的 线性理解已遭到质疑。[10]

控制论的第二次思潮可以与大都会建筑事务所 (OMA) 的两个景 观设计项目进行比照。其中一个是OMA于1982年参加的法国拉 - 维莱 特公园设计竞赛作品, 另一个是于 20 世纪 90 年代末参加的加拿大当斯
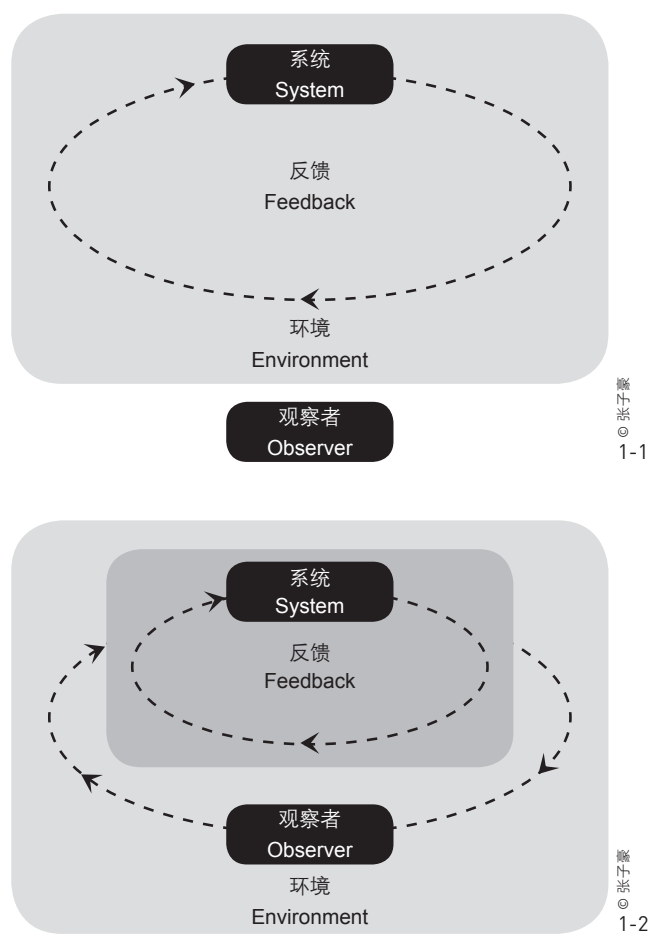

known as second-order cybernetics, to include observers as part of the cybernetic system (Fig. 1). This conceptual shift gave rise to the second wave of research from the late $1960 \mathrm{~s}$ to the 1970s, in which scholars focused on observing systems and their role in the model-making process. Chilean biologists Humberto Maturana and Francisco Varela introduced the term "autopoiesis" (self-production) to conceptualize how systems use the material and information flow to maintain their identities ${ }^{[9]}$. Varela then ventured into the field of artificial life, thus connecting the third wave of cybernetics research in the early 1990s. The key concepts are emergence and complexity. Through the experiment of artificial life-a multi-agent simulation-scholars posit that complex phenomena such as intelligence and consciousness are, in fact, results of interactions between distributed systems. The third wave of research thus has challenged human exceptionalism and given rise to a range of posthumanist considerations since the late $1990 \mathrm{~s}^{[8]}$.

A body of landscape research and projects can be contrasted with the three waves of cybernetics in terms of their major concerns (Fig. 2). McHarg's ecologically inspired design methodology can be understood as a version of landscape control through first-order cybernetics. To control a mechanical system, engineers usually manage the entropy to maintain the system's homeostasis. In thermodynamics, entropy refers to the tendency of a system to move into disorder and chaos. McHarg used the concept of entropy extensively throughout his writing and always compared entropy with ecological fitness. For McHarg, entropy is another term for uncertainty, which poses a threat to the integrity of the ecosystem. Thus, landscape designers' work is to control landscape change by following a set of ideal models of ecological successions and finally reach an equilibrium state as expressed in the "climax stage" of an ecosystem $^{[7]}$. From a perspective of contemporary landscape theories and practices that focus on open-endedness and emergence, McHarg's design framework has been critiqued for its inherent environmental determinism and linear understanding of ecological processes. ${ }^{[10]}$

The second wave of cybernetics can be contrasted with two landscape projects by OMA. The first one is the entry for the Parc de la Villette competition in 1982, and the second is the entry for Toronto's Downsview Park competition in the late 1990s called "Tree City"[11][12]. The two projects can be understood as a seriation in which the designers deployed the tactic of "self-production" of the park system as design strategies, and the urban parks were understood as an autopoietic (selfproducing) system that uses flows of material and information to reproduce their own organizations. An autopoietic system 


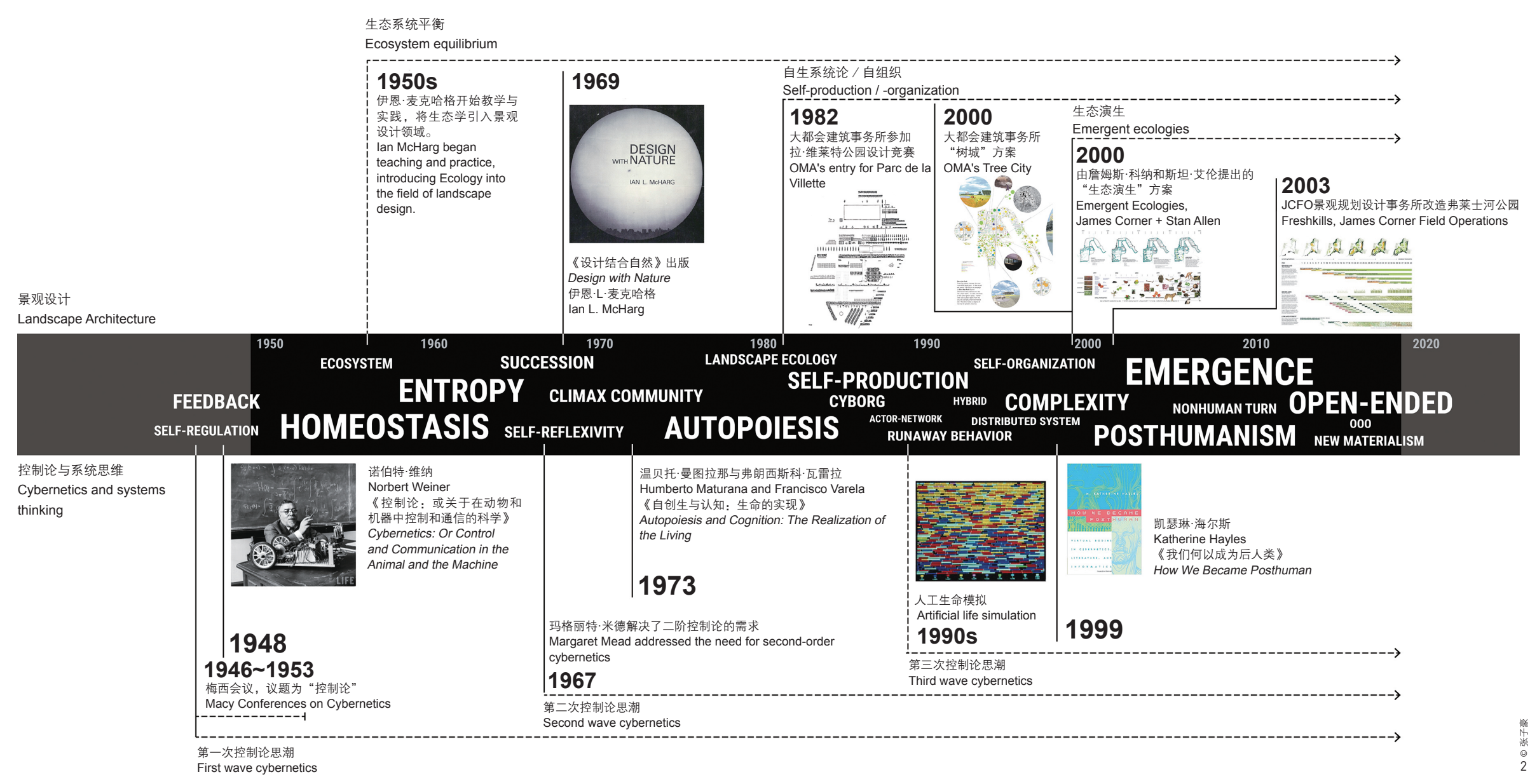

控制论与景观设计

Cybernetics and Landscape Design

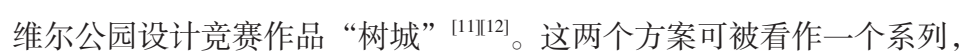
它们都利用 “自生系统” 作为设计策略, 将公园理解为一个自组织 系统, 即利用物质和信息不断复制自己的体系。所谓自生系统, 是指 系统通过其内部组织关系来处理信息物质流，从而维持自身特性。例 如, 在当斯维尔公园竞赛中, OMA用 1000 条道路构成的路网和植物簇 群作为空间框架, 分割出大片未进行功能限定的区域, 以满足公园未 来发展需求。乍看之下, OMA的 “树城” 表现出一定的不确定性, 因 此是开放的。但是, 这种灵活性是基于城市公园系统的自我生产, 从 而维持了另一个层面上的稳态, 这种对稳态的控制可以由二阶控制论 解释 ${ }^{[13]}$ 。景观设计师、理论家克里斯蒂娜 - 希尔对 OMA的设计持强烈 的怀疑态度, 她指出, 尽管OMA的文案中描述了一个高度灵活的设计 框架, 但这个设计本质上还是一个传统的田园牧歌式的城市公园 ${ }^{[14]}$ 。换 言之, 场地通过系统运转来维持其作为 “田园式公园” 的系统组织, 几乎没有为景观演生和未知的发展可能预留任何空间。

由詹姆斯 - 科纳事务所、斯坦 - 艾伦与生态学家尼娜一玛丽 - 利 斯特合作的参赛作品 “生态演生” ${ }^{[15]}$ 可以和控制论的第三次思潮进行比 照。第三次思潮注重开放性和演生, 而该设计方案的框架将使场地通 maintains its identity by processing the flow of information and material using its components and relationships. For example, in the Downsview Park competition, OMA proposed a 1,000-path network and vegetal clusters separated by vast undesignated areas as a spatial framework to account for the future development of the park. It appears that OMA's Tree City exhibits some level of uncertainty, thus being open-ended. However, this flexibility is on the basis of self-production of the urban park as an autopoietic system, thus maintaining another level of homeostasis by legitimizing a control regime based on second-order cybernetics ${ }^{[13]}$. Landscape architect and theorist Kristina Hill was highly critical towards OMA's proposal, and she pointed out that despite the language which renders a flexible framework, OMA essentially proposed a traditional urban park with pastoral forms ${ }^{[14]}$. In other words, the site operates to maintain its system organization as a "pastoral park," leaving little room for the consideration of emergence and unfolding of how the landscape could become.

Another entry for the Downsview Park Emergent Ecologies ${ }^{[15]}$ from the collaboration between James Corner Field Operations, Stan Allen, and ecologist Nina-Marie Lister can be contrasted with 
过生态演生的方式实现长期发展。不同于其他人围方案将建设城市公 园作为 “最终目标” 的分阶段式设计构想, “生态演生” 将为期 15 年 的最初阶段作为一种培育场地长期潜力的策略。这一设计将为建成后 的场地发展提供多种可能性。换言之, 该方案不是为了建造一个按照 预期发展的、稳定的城市公园, 而是意在把场地打造为一片潜力无穷 的区域。该方案为人们预留了足够的想象空间, 描绘了一个生机勃勃 的场所, 这是与 “田园式城市公园” 的本质区别 ${ }^{[16]}$ 。

通过比较景观设计和控制论运动, 可以看出三种不同的设计研究 范式是如何阐释控制与不确定性的 (图2)。在一阶控制论框架内, 不 确定性表现为模型与环境间的差异, 要想消除这种差异则需要不断获 取新知; 另一方面, 设计师通过采取合适的方法来获得更多的知识, 并通过构建更复杂的模拟机制来缩小模型与环境间的差距, 从而消除 或控制不确定性。而在自生理论框架内 (即第二次思潮), 不确定性 成为了一种信息流和物质流, 以及系统维持自身特性的一种手段, 这 种控制手段只能通过二阶控制论来解读。而在开放和演生的框架内 (即第三次思潮), 不确定性成为了一种潜能, 它不再是一个负面的 概念, 不再像麦克哈格所认为的熵那样需要加以规范和控制。相反, 正是由于不确定性, 未来才充满无限可能。

\section{3 反馈生物与模拟实验}

在演生和开放的理论框架内, 原型发挥着重要作用, 它能够帮助 人们发掘不确定性中蕴含的潜力。作为一类特殊的模型，原型应该被 置于控制论的发展进程中来理解，并分析这一概念在系统思维中的形 成过程。在某种程度上, 原型一直存在于控制论运动中, 但其效用长 the third wave of cybernetics which focuses on open-endedness and emergence. The team also proposed a framework that allows for a long-term generation of the park based on emergent ecologies. Unlike other finalists which used phasing programs to build an urban park as an end point, Emergent Ecologies considered the initial 15 -year phasing program as a strategy to cultivate the long-term potential of the site, providing multiple possibilities of how the site could be used after its construction. In other words, constructing a conceivable and stable urban park was not the goal of this proposal; instead, the aim was to prepare the Downsview site into a territory with a wide range of possibilities. The proposal leaves plenty of space to imagine a place that is wild and vibrant and is fundamentally different from a pastoral urban park ${ }^{[16]}$.

Contrasting landscape design with the cybernetics movement highlights how control and uncertainty were conceptualized in three paradigms of design and research (Fig. 2). Within a firstorder cybernetics framework, uncertainty represents the modelenvironment difference that needs to be reduced by gaining more knowledge about the phenomenon that we study. On the other side of this reasoning, designers can acquire knowledge by deploying proper means and close the gap between the model and the system by building more complex stimulation mechanisms, and uncertainty can be reduced and managed.

Within the autopoiesis framework (second wave of cybernetics), uncertainty is instrumentalized as information and material flow that supports the system to maintain its own identity, thus legitimizing another kind of control regime that can only be articulated with second-order cybernetics. Within the framework of emergence and open-endedness (the third wave), uncertainty is transformed into potentiality. It is no longer a negative concept, like entropy in McHargian's terms, that needs to be regulated and controlled. Instead, because of the uncertainties, the future can be articulated to have a wide range of possibilities, thus becoming resourceful.

\section{Cybernetic Creatures and Designers' Simulation}

In the framework of emergence and open-endedness, prototypes act as an important component to help exploit the potential embedded in the uncertainty. Since a prototype can be understood as a special family of models, which should be situated in the history of cybernetics movement and analyze how it was conceptualized at large in systems thinking. In a way, prototypes have always existed in cybernetics movement, but the habitual means-end reasoning has limited their "usefulness." By analyzing a range of cybernetic creatures within the emergence 
期受限于手段一目的链思维方式。通过在演生框架内分析一系列反馈 生物，人们得以跳脱出手段一目的链的逻辑，转而重视原型思维。

\section{1 “蛾” 或 “息虫”、细胞自动机和人工生命}

早期的控制论学者通过设计反馈机和模拟实验进行理论检验。 其中一项重要成果是由维纳设计的反馈机，也被称为 “蛾” 或 “臭 虫”。在《人有人的用处》一书中, 维纳详细讨论了如何通过制造反 馈机来构建实体模型, 以演示人类神经系统中姿态反馈和自愿反馈 (或寻求目标时的反馈机制) 两种机制间的相互作用 ${ }^{[19]}$ 。维纳断言, 这 两种反馈机制存在于人类行为中，而神经系统疾病（如帕金森症和意 向性鲴抖）就是由于这些反馈机制过载崩溃而导致的。维纳进一步指 出，在帕金森症中，自愿反馈会抑制和调节姿态反馈：患者在休息时 会发生颤抖, 而当他们执行任务 (即寻求目标) 时, 颤抖便会减弱甚 至消失。维纳系统通过设计一种装置来演示这两种反馈机制。

维纳和他的同事制作了一个叫做 “蛾” 或 “臭虫” 的装置, 这个 装置像一个小三轮车, 有正趋光性 (蛾) 和负趋光性 (臭虫), 有两 种可以相互调节的反馈机制。以 “蛾” 功能为例, 小车前端装有两个 光敏管, 当有灯光时, 电机便会将前轮转向有光的方向。但此动作将 触发另一个负反馈电路, 该负反馈电路会使前轮朝相反方向转动。因 此, 这个小车便会摇摆着移向光源（有目标的自愿反馈）。当没有灯 光时, 由于电位器和电机之间存在次级反馈, 小车仍将摇摆着继续前 进（姿势反馈）。而通过调节电路中的放大器使该反馈电路过载时, 摇摆幅度会变大。因此, 这个装置可以模拟帕金森症, 其中的自愿反 馈可抑制和调节姿势反馈（图3）。[17]

“蛾”可被看作反馈机制的实体示意模型，而反馈机制是第一 次思潮期间梅西会议中的一个重要概念。然而, 手段一目的链不能解 释 “蛾” 的用途, 因为当控制论学者制造它的时候并没有一个具体的 framework, it starts to articulate prototyping outside the meansend equation.

\subsection{The Moth or the Bedbug, Cellular Automaton, and Artificial Life}

Early cyberneticians built cybernetic machines and simulations as a way to test out their theoretical considerations. An important artifact was Wiener's cybernetic machine known as "the moth" or "the bedbug." In The Human Use of Human Beings, Wiener discussed in detail the process of making this "cybernetic robot" to build a working model of the interaction of two kinds of feedback mechanisms in the human nervous system: postural feedback and voluntary feedback (goal-seeking feedback) ${ }^{[19]}$. Wiener asserted that these two types of feedback mechanisms exist in human behavior and nervous system disorders, and Parkinsonism and intention tremors are the cases when these feedback mechanisms are overloaded and broken down. Wiener further posited that in Parkinsonism, voluntary feedback regulates postural feedback: the tremor happens when the patients are in rest, and when the patients perform a task (goal-seeking), the tremor subsides or even disappears. Wiener expected to conceptualize these theoretical explanations in action by building an apparatus that could act based on the two kinds of feedback mechanisms.

Wiener and his colleagues built a machine called "the moth" or "the bedbug." It was a three-wheeled cart with two major modes of action, positively photo-tropic (the moth) and negatively photo-tropic (the bedbug). This machine has two types of feedback mechanisms with one regulating the other. For example, to achieve the "the moth" function, the cart carries two photo-cells in the front, and when there is light, the motor will turn the wheel towards the direction of the light. This action will trigger a negative feedback circuit that turns the front wheel in the opposite direction. So, the cart will move towards the light in an oscillating pattern (voluntary feedback). If there is no light, the cart will keep oscillating because there is secondary feedback between the potentiometer and the motors (postural feedback). Moreover, when this feedback is overloaded by adjusting the amplifier in the circuit, the oscillation would grow bigger. This machine was argued to be an analog to Parkinsonism, in which the voluntary feedback suppresses the postural feedback (Fig. 3). ${ }^{[17]}$

"The moth" can be understood as a physical diagram of feedback mechanism, which was a key concept explored in the first wave of cybernetic research in the Macy Conferences era. However, its "usefulness" cannot be conceptualized within the means-end equation because when the cyberneticians built it, they did not have a specific goal in mind, such as solving a 


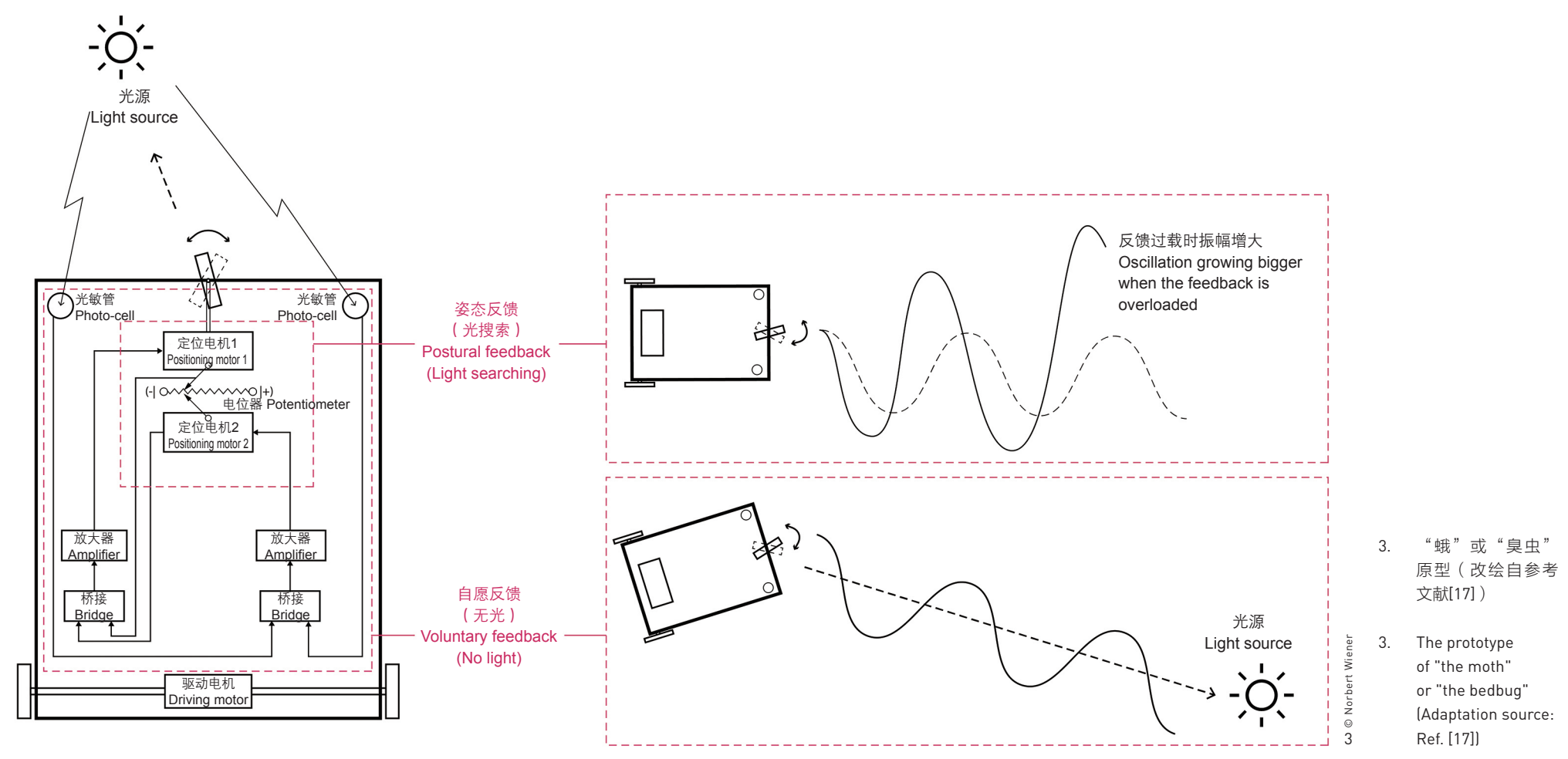

目标 (比如要解决某个问题)，所以 “蛾” 也并非达成目的的手段, 学者们仅想通过它生动地演示控制论原理。在演生框架内, 如果将 “蛾” 看作原型来理解, 那么它的价值恰好在于其不确定性。由于它 是反馈机制的一个抽象的示意模型，因此不同领域会对它产生不同的 解读, 而这种发散性思维正是创作和设计的基础。由此, “蛾” 成为 了一种存在于不同领域之间的临界物，帮助学者思考和讨论控制论原 理，这对于早期控制论原理的普及有着重要作用。[18]

另外两个需并置讨论的例子分别是冯 - 诺伊曼的细胞自动机和 人工生命实验。设计细胞自动机是为了研究 “自我复制机” 的逻辑需 求。它可被看作一个二维网格, 每一个单元格 (细胞) 都代表了一个 有限状态自动机, 在任何特定时间内, 每一个单元格都处于一种有限 状态之中, 都可向相邻单元格传输信息。在冯 - 诺伊曼的模型中, 每 个单元格都有 29 种不同的状态, 代表了 29 种信息传输规则。例如, 若 一个单元格在三个周期内都处于被激活状态, 那么当它接收到来自相 邻单元格的信息后, 则会进人传输状态, 并将信息传输至其上方单元 格中。关于传输状态也有一些规则, 例如, 当处于基础状态的空单元 格接收到信息时, 空单元格便会进人被激活状态。如果两个单元格互 problem. Thus "the moth" is not a means to an end. Cyberneticians were simply interested to see the cybernetic principles in action. In the framework of emergence, "the moth" can be understood as a prototype, whose value lies in its uncertainty. Because it functions as an abstracted diagram of feedback mechanism, it can be interpreted differently among different fields, and the proliferation of meaning is the basis of creativity and design. It became a kind of boundaryobject that facilitated the thinking and communication of cybernetic principles between scholars from different fields and played a critical role in popularizing the cybernetic principles in its early stage. ${ }^{[18]}$

The other two examples-von Neumann's cellular automaton and artificial life experiment-can be discussed as a seriation. The cellular automaton was designed to provide insight into the logical requirements for self-replicating machines. It can be understood as a 2D grid, and each cell presents a finite-state automaton or machine, which can be in one of a finite number of states at any given time. Cells can transmit input to its adjacent cells. In von Neumann's model, each cell has 29 different states, which can be understood as rules for transition signals. For example, if a cell is in the sensitized state for three cycles, and it receives an input from an adjacent cell, it will enter a transmission state that will pass the data to the cell to its north. There are also rules for transmission state. For example, when an input is given to a cell that is in the ground state (an empty cell), the cell will enter the sensitized state; if somehow two cells 
相传输信息，那么信息就会被清空。当然，还有其他一些用来决定相 邻细胞间互动的规则。 ${ }^{[19]}$

人工生命实验比细胞自动机的机制更加复杂。生物学家受到自生 系统论的启发，想要探索二阶控制论的广泛意义，以及自生系统如何 脱离其原有轨迹并朝新的方向发展。其中一项著名实验是Tierra程序的 编写，该程序可以基于简单的规则进行自我复制和变异，当程序将代 码写人内存条时, 会随机反转 1 和 0 形成一串新代码。假如新代码恰好 是某个其他程序的机器代码, 那么旧有程序就可以说是发生了变异。

一旦计算机内存溢出, “淘汰” 功能就会把旧有的或有缺陷的程序

“杀死”。通过重复这一简单过程, 一个电脑程序可以进化出五花八 门的 “数字物种” , 形成各式各样的 “生态系统” ${ }^{[20]}$ 。人工生命实验对 于后人类主义的讨论起着重要作用, 它证明了复杂行为 (如人类的思 考行为) 不过是分布式系统 (如神经网络) 之间的相互作用产生的附 带现象而已，而这样的认知也为海尔斯在内的后人类主义支持者挑战 人类例外论提供了理论支持。 ${ }^{[8]}$

这些反馈生物的范例没有明确定义，可被灵活解读，这些特性 使它们成为了不同于当代环境设计实践 (如适应性管理) 中使用的预 测性模型的原型。预测性模型具有隐喻性, 用于反映某种现实中的现 象，也与现实环境存在差异。因此，在预测性模型中，这种差异被视 为威胁控制策略的不确定性。然而, 原型却具有双重属性。一方面, 和预测性模型一样，原型也具有隐喻性，即用一种事物来指代另一种 事物—— “蛾” 即为反馈机制的示意模型; 另一方面, 原型来自于现 实世界, 故而具有现实性, 可以不断衍生出其他事物。这种双重特性 使原型成为一类特殊的模型，这种模型不用于预测或决策，而是为人 们带来启发和洞见。

\section{2 案例研究: 水文地貌模拟沙床}

在水力学模型的研究和工程实践中, 大型物理河流模型通常用于 模拟气象和雨洪事件, 以及评估防洪措施的效果, 如 20 世纪 50 年代由美 国陆军工兵团建造的密西西比河流域模型和旧金山湾区模型 ${ }^{[21]}$ 。另一方 面, 数字模型和模拟也广泛用于环境设计实践中, 以预测系统行为并 transmit data to each other, then data disappear. Other rules guide how each cell interacts with its neighbors. ${ }^{[19]}$

The artificial life experiment is a more complex version of the cellular automaton. Inspired by autopoiesis theory, biologists wanted to explore the implication of second-order cybernetics and how self-production systems can spin off and evolve towards new directions. One famous experiment is called Tierra-A computer program designed to replicate and mutate based on simple rules. The self-replicating program would randomly flip ones and zeros on the computer memory when copying the data. If the new data happened to be machine code for another program, the original program mutated. A "reaper" function would "kill" old or defective programs when the computer memory became full. By repeating this simple process, a computer program could evolve into different "ecosystems" with a wide range of digital species ${ }^{[20]}$. The artificial life experiment had a high value in the discourse of posthumanism because it showed that complex behaviors, such as human thinking, were epiphenomenon of interactions between distributed systems, such as neural networks, and this realization allowed posthuman proponents, such as Hayles, to challenge human exceptionalism. ${ }^{[8]}$

The interpretation flexibility and undefined identity of these examples of cybernetic creatures make them prototypes, which are different from the predictive models used in contemporary environmental practices such as adaptive management. A predictive model entails a model-environment difference, as the model has a metaphorical quality, and it represents a phenomenon in reality. With predictive models, the gap between the model and the environment is conceptualized as uncertainty that can only be conceptualized as negative forces undermining control regimes. Nevertheless, a prototype has a twofold quality. On the one hand, like predictive models, a prototype has metaphorical quality, that is, it uses one thing to refer to another thing; "the moth" is a working diagram of feedback mechanisms. On the other hand, it has a sense of realism in it because it exists as part of reality so that other artifacts can be said to be derived from it. This twofold quality makes prototypes a special type of model that does not predict or determine, but inspire and anticipate.

\subsection{A Case Study: Hydromorphology Table}

In the scientific and engineering practice of physical hydraulic modeling, large physical river models are built to simulate weather and flood events and to evaluate the effect of flood control strategies. Precedents include large-scale hydraulic models built in the 1950s by the Army Corps of Engineers such as the Mississippi Basin Model and the San Francisco Bay Model ${ }^{[21]}$. On the other spectrum, digital models and simulations are also widely used 
评估控制策略, 如南佛罗里达州水管理模型 ${ }^{[22]}$ 。物理模型和数字模型都 是通过手段一目的链来进行预测和控制。这些模型代表了某种理想状 态, 通过映射在环境中来指导环境改造。但正如朱利安所言, 如果我 们沿用手段一目的链思维方式来思考问题, 总会遇到模型预测范围之 外的意外情况, 那么控制与不确定性之间的矛盾似乎永远无法调和。 数字工具和运算方法的进步为景观设计师提供了有别于预测性模型和 手段一目的链思维方式的新的原型。为了更好地阐述原型如何辅助设 计思维, 本文将介绍一系列基于水文地貌模拟沙床 ( 以下简称 “沙 床” ) 的案例, 以进一步说明原型的特性以及原型思维的价值。

哈佛GSD的REAL实验室基于Emriver径流模型建造了一个沙床 ${ }^{2}$ 。 Emriver径流模型这一常用于水文研究的模型被作为一种原型思维平台 而引人景观设计学领域, 以帮助设计师更好地了解水文地貌变化的过 程, 并辅助制定响应式设计策略。设计师可以通过 4 个进料器和一个水 泵来控制沉积物和水流的输人, 用以模拟水流和沉积物的变化。 此外, 设计师不仅能够通过调整变量来研究同一水文系统的迭 代, 也能在相同流量和沉积物输入的条件下测试不同系统的径流情 况。除了Emriver模型本身自带的仪器外, REAL实验室的原型平台还 配备了感应和监控设备 (如在沙床上方安装的微软体感设备Kinect, 以及位于沙床下游的超声波传感器），以收集实时数据。收集到的 数据通过Grasshopper软件中的自定义插件实时传输到三维建模软件 Rhinoceros中。

近年来, 作为一种原型思维平台, 沙床被广泛运用于研究和设计 项目中, 这些项目展现了构建自主系统的可能性, 而自主系统能提出 超越人类理解范畴的策略并创建 “野生” 场所 ${ }^{[23]}$ 。例如, 设计师雷夫 · 埃 斯特拉达在 “走向感知” 项目中，测试了 “感应一处理一制动” 的响 应式框架 ${ }^{[24]}$ 。在一项设计实验中，埃斯特拉达提出了一种称为 “调制 in environmental practices to predict system behaviors and evaluate control strategies, such as the South Florida Water Management Model ${ }^{[22]}$. These models, physical or digital, are all envisaged in the line with means-end relationships for prediction and control. The models begin as an ideal representation of the environment so that they can be projected and used to give form to reality. However, as pointed out by Jullien, following this line of reasoning, there will always be unexpected circumstances outside the scope of predictions that are allowed by the models. Thus, one is constantly challenged by the tension between control and uncertainty. Development in digital tools and computational methods has provided landscape architects with advanced techniques to build prototypes that challenge the predictive models and means-end reasoning. To better illustrate how prototyping helps with design thinking, this paper presents a series of case studies based on a hydromorphology table to demonstrate the qualities of prototypes and the value of prototyping.

The hydromorphology table was based on the Emriver stream table and was located at the REAL in Harvard GSD $^{2}$. The Emriver stream tables, which were usually used by hydrologists, were introduced to the field of Landscape Architecture as a prototyping platform to help designers better understand hydro-morphological processes, and to facilitate the production of responsive design strategies. The inputs of both the sediments and water flow were controlled through 4 material feeders and a water pump to simulate water flows and behaviors of sediment. The table allowed for running iterations of the same hydromorphological system with measurable adjustments, as well as testing multiple systems with the same flow and sediment input. Besides the instruments provided by the Emriver, the prototype platform was also equipped with sensing and monitoring devices to gather real-time data, including a Microsoft Kinect above the table and ultrasonic sensors down the stream. The real-time data then were fed into Rhinoceros 3D through grasshopper plugins and customized interfaces.

As a prototyping platform, the hydromorphology table facilitates many research and design projects over the years, shedding light on the possibility of constructing autonomous systems that can devise strategies beyond human comprehension to create "wild" places ${ }^{[23]}$. For instance, designer Leif Estrada tested the sensing-processing-actuating responsive framework in the project Towards Sentience ${ }^{[24]}$. In one of the design experiments, the designer proposed an actuating system called "attuner" that consists of a matrix of acrylic dowels connected to servo motors. Every servo motor drives a dowel, the bottom of which sticks into the sediments. When the servo motors 网站。

(2) For more information about Emriver stream table and the hydromorphology table at the REAL in Harvard GSD, please visit the websites of Emriver stream table and REAL. 
器” 的系统，该系统由连接到伺服马达的一组亚克力杆组成。每个亚 克力杆均由伺服马达单独驱动, 其底部插人沉积物中。当伺服马达转 动时, 会驱动亚克力杆上下移动来改变水流形态, 从而在沙床的下游 形成不同的地形。随后, 通过沙床上方的Kinect传感器实时跟踪地形, 形成数字高程模型, 以识别出地势的高低。这些信息会反馈到制动系 统, 这样就能在高地上借由更多的沉积物来造陆, 或引流更多的水体 来侵蚀陆地。埃斯特拉达描述道，水文地貌模拟沙床构建的控制系统 具有实时更新和反馈能力，而这种自主能力是人类无法企及的 ${ }^{[25]}$ 。

在另一个示例中，设计师刘浔基于实体界面（TUI）的概念开发了 一种混合仿真模型 ${ }^{[26]}$ 。TUI逐渐取代了传统的图形用户界面（GUI）, 它结合了物理模型和数字模型的优势, 现已被广泛用于增强物理模型 性能以及物理模型的数据可视化, 从而实现 “比特和原子” 的无缝耦 合 ${ }^{[27]}$ 。自定义程序使用从Kinect传感器感测到的高程数据来生成实时 数字地形模型, 该模型可在Rhino和其他软件中用于进行水流、植被分 布、污染物和沉积物等不同类型的数值模拟（图4）。地形变化、景观 turn, they drive the dowels moving up and down to change the flow pattern, creating different landforms in the downstream of the table. The topography is then live tracked by the Kinect sensor above the table, forming a digital elevation model of the topography so that a series of high grounds and low grounds can be identified. This information then feeds back to the actuating system so that it could either build more land in a high ground by depositing more sand on it or erode the high ground away by directing more water towards it. The designer described that the cyborg system built with the hydromorphology table exhibited a level of live updates and feedback that was beyond human capacity ${ }^{[25]}$.

In another example, designer Liu Xun developed a hybrid simulation based on the concept of the Tangible User Interface $(\mathrm{TUI})^{[26]}$. TUI is increasingly accepted as an alternative paradigm to the conventional Graphic User Interface (GUI). It combines the benefits of physical and digital models in the same representation and is widely used to enhance the performance of physical models and visualize the unseen data beneath the physical model, creating a seamless coupling of "bits and atoms" ${ }^{[27]}$. The customized program uses the sensed elevation data from the Kinect sensor as input to generate a live digital terrain model, which can be used in Rhino and other softwares to conduct numerical simulations for different purposes such as water flow, vegetation distribution, pollution, and sedimentation (Fig 4). Topographic changes, landscape morphology, water streamline, and patterns of other simulated agents can be
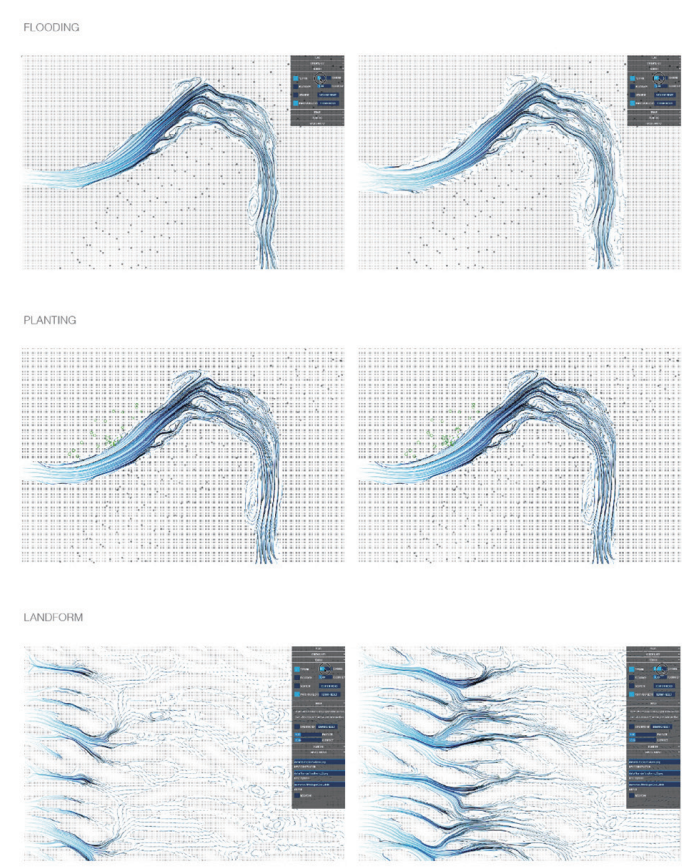
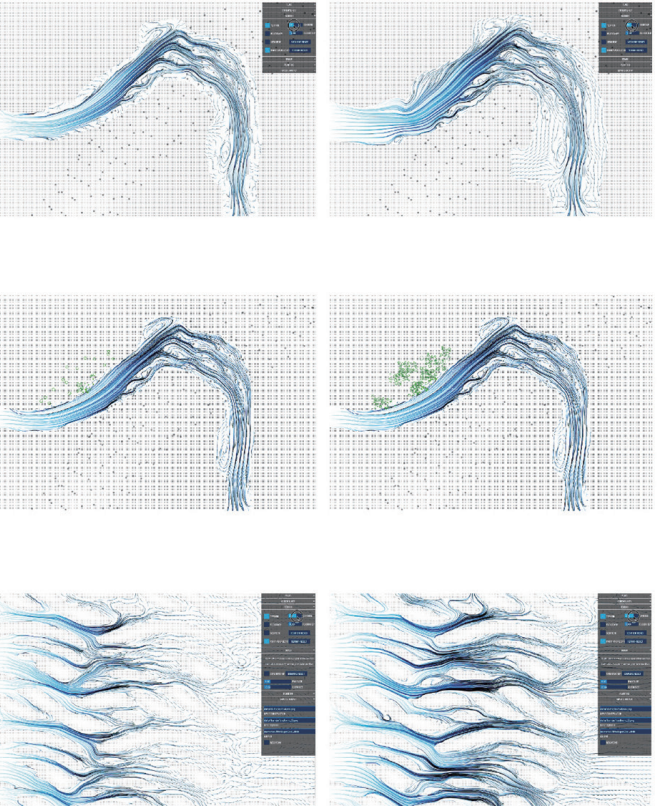
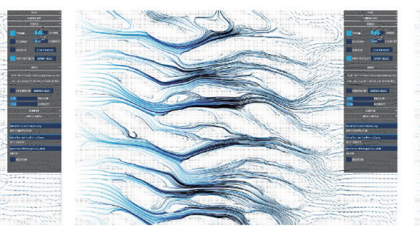
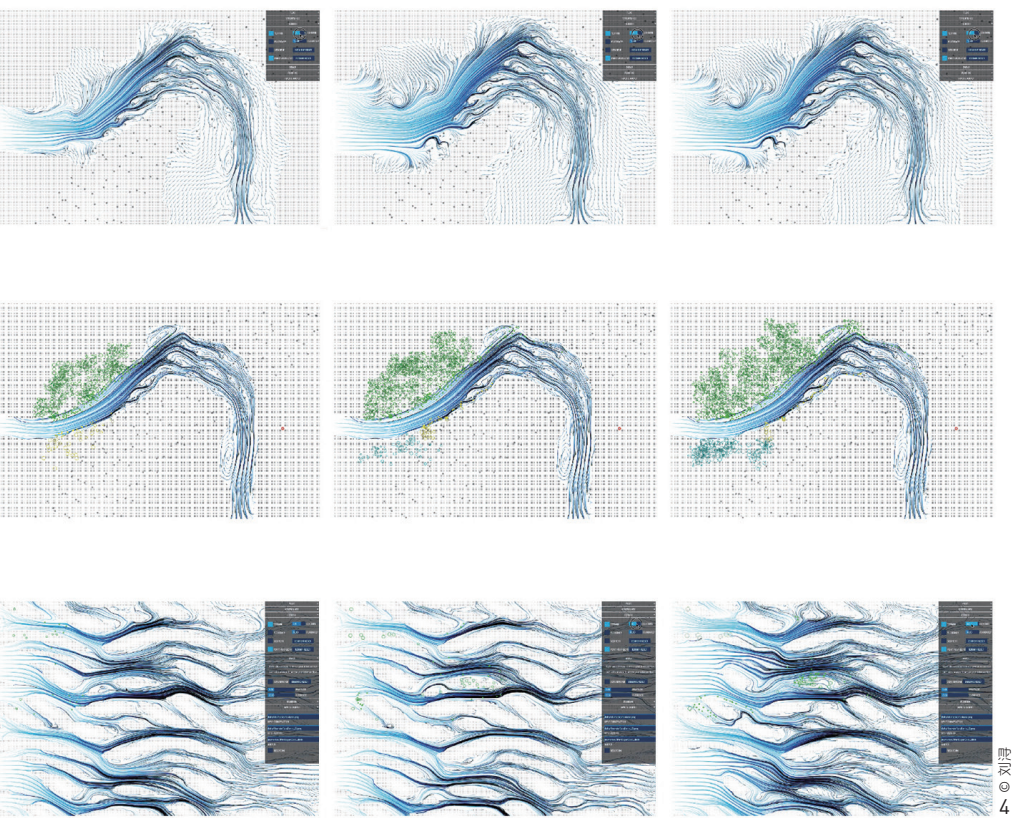
形态、水流线, 以及其他模拟图像都可通过短程投影仪投射到沙床上 (图5)。如此, 基本的地形分析与动态流体模拟被集成到同一个平台 中, 可以更好地实现地形数据的可视化, 数字模拟和物理模拟也能通过 反馈回路实现耦合。设计师可以依据沙床上的投影信息（如等高线和填 方图）即时手动调整物理模型（图6 9）。

增强现实的沙床可成为景观设计师新的设计工具, 也可被当作一 种合作平台, 帮助社区参与中的不同利益相关者进行沟通协商。该原 型并非基于从设计构思到计算机模拟、再到材料处理和结果呈现的线性 设计过程, 而是开启了一种新的工作流程, 其支持设计过程中的不同步 骤同时或反复进行。本实验中讨论的实体交互概念超越了界面的接触, 是指两种不同类型的模拟的协同与组合: 数字模拟可用于验证物理模 拟, 物理模拟可用于检测数字模拟, 两种模拟相互配合并彼此适应。 通过运用增强现实技术将物理河流模拟与实时的数字河流模拟相整 合, 该原型使景观设计师可以直观地利用有形的材料进行设计, 并同 步获得计算模拟结果的校验。作为设计师与实体空间之间的动态界面, 实体交互模型的变化性和不确定性对于理解水力形态过程的复杂性和动 态过程非常重要。

需要特别指出的是, 沙床模型并没有按照真实景观比例来建造, 所以该原型不宜用来模拟特定地点的水文和生态系统。换句话说, 如果 以手段一目的链来理解沙床的概念, 那么沙床必须按照真实环境的比例 来建造, 这样才能用于预测设计结果并决定相应策略 (如密西西比河流 域模型或南佛罗里州达水管理模型）。但是，围绕模型制作的讨论最终 离不开如何用模型 “精确” 地表达环境的问题, 这与模拟参数的不确定 性有关。在建模中, 造成不确定性的原因有很多, 如结构的不确定性、 算法的不确定性等。其中, 参数的不确定性来自模型输人变量的可变 性。对于沙床而言，设计人员可以通过调整介质的大小以及不同介质之 间的比例改变河道 “沉积物” 的组成, 进而调节水流的速度和流量。这 些都是模型本身包含的变量, 更改其中的任何变量都将对模拟结果产生 显著影响。如果将沙床视为一个预测性模型, 那么设计人员需要计算建 模过程中的所有参数值, 以最大程度地减少参数的不确定性。设计人员 不仅必须选择合适的材料尺寸来模拟真实的景观环境, 而且需要确定恰 当的材料构成比例, 更不用说计算缩放过程中涉及的物理变化, 因为理 论上除了水以外, 所有事物都被缩小了。为了解决这个问题, 设计人员 必须找到另一种具有适当粘滞阻力的流体, 以代表流体与要按比例缩放 的固体颗粒之间的相互作用。由此可知, 如果遵循手段一目的链来理解 沙床, 会不可避免地将它看作一种重构现实世界的理想模型，而这种想 法会导致不确定性永远存在。最重要的是，这种基于手段一目的链框架

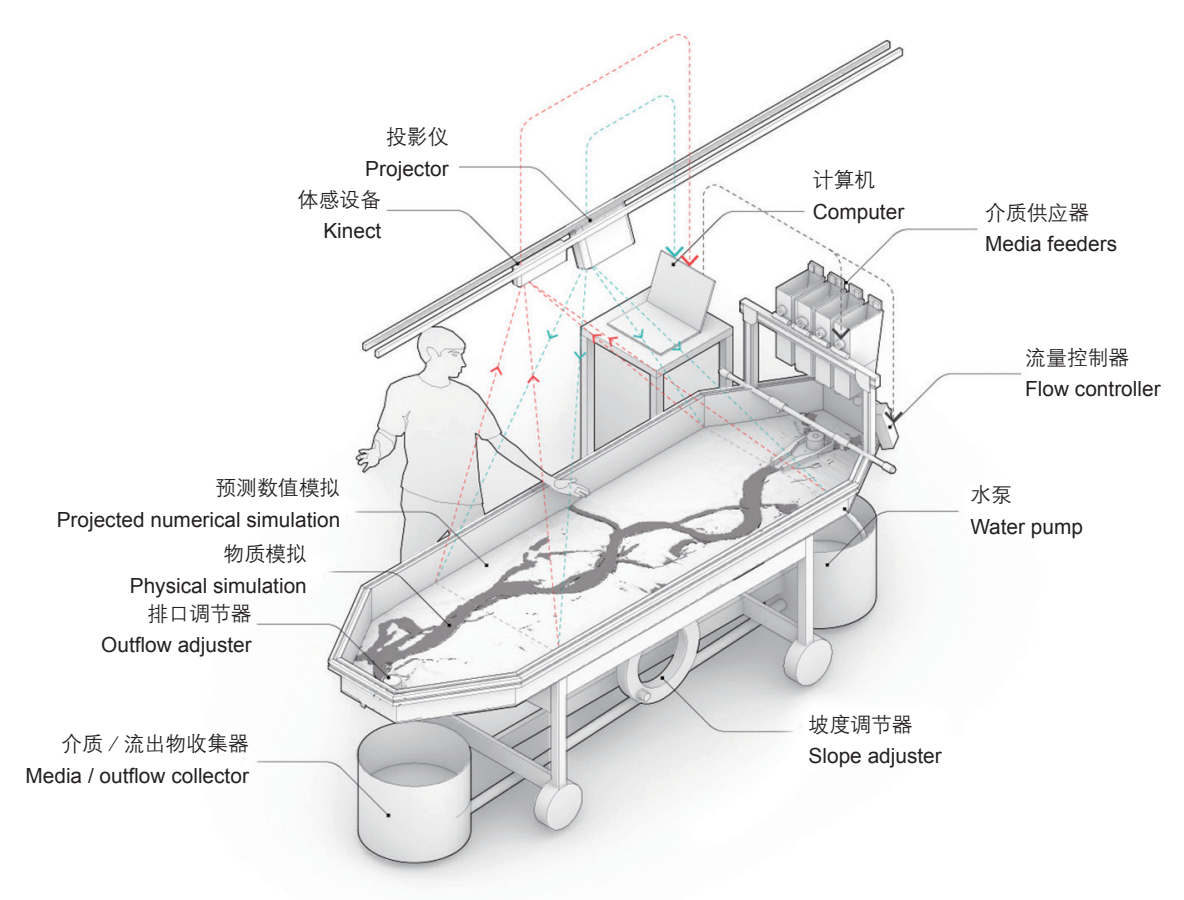

$\sqrt{2}$
0
0
5

visualized in diagrammatic representations. These representations then can be projected back onto the hydromorphology table with a short-throw projector (Fig. 5). In such a way, basic terrain analysis is integrated into this platform together with dynamic fluid simulation to better visualize the invisible aspects of the topography, and the digital simulation and the physical simulation are coupled through a feedback loop. Designers can manually change the physical model according to the projected information, such as contour lines and cut-and-fill maps (Fig. $6 \sim 9$ ).

This augmented hydromorphology modeling table can be used as a new design tool for landscape designers, as well as a cooperation platform for community engagement and communication between different stakeholders. Rather than developing design in a linear progression from idea to computersimulated model, and material manipulation and result, this prototype inspires an alternative workflow that allows different steps in the design process to play concurrently or recursively. The concept of tangibility developed in this experiment is more than the tangibility of the interface, but the synthesis and composition of the two different types of simulation: numerical models being used to manipulate while validating physical models, and vice versa. Two kinds of simulations feed and adapt to each other. By integrating physical hydraulic simulation with the real-time computational fluvial simulation through augmented reality technologies, this prototype allows landscape architects to design intuitively with tangible material processes and simultaneously be 5. Augmented hydromorphology table control system 
增强现实沙床地形实验 计师能通过投影, 直设 师能通过投影, 直观 感受设计干预对水文系 统的影响。

8. 现实增强的地形分析

9. 软件操作界面

6. Augmented hydromorphology table: landform experiment

Agent-based

simulation. Designers can observe the direct impact of design intervention on the hydrological systems through projected simulation. topographical analysis Software interface
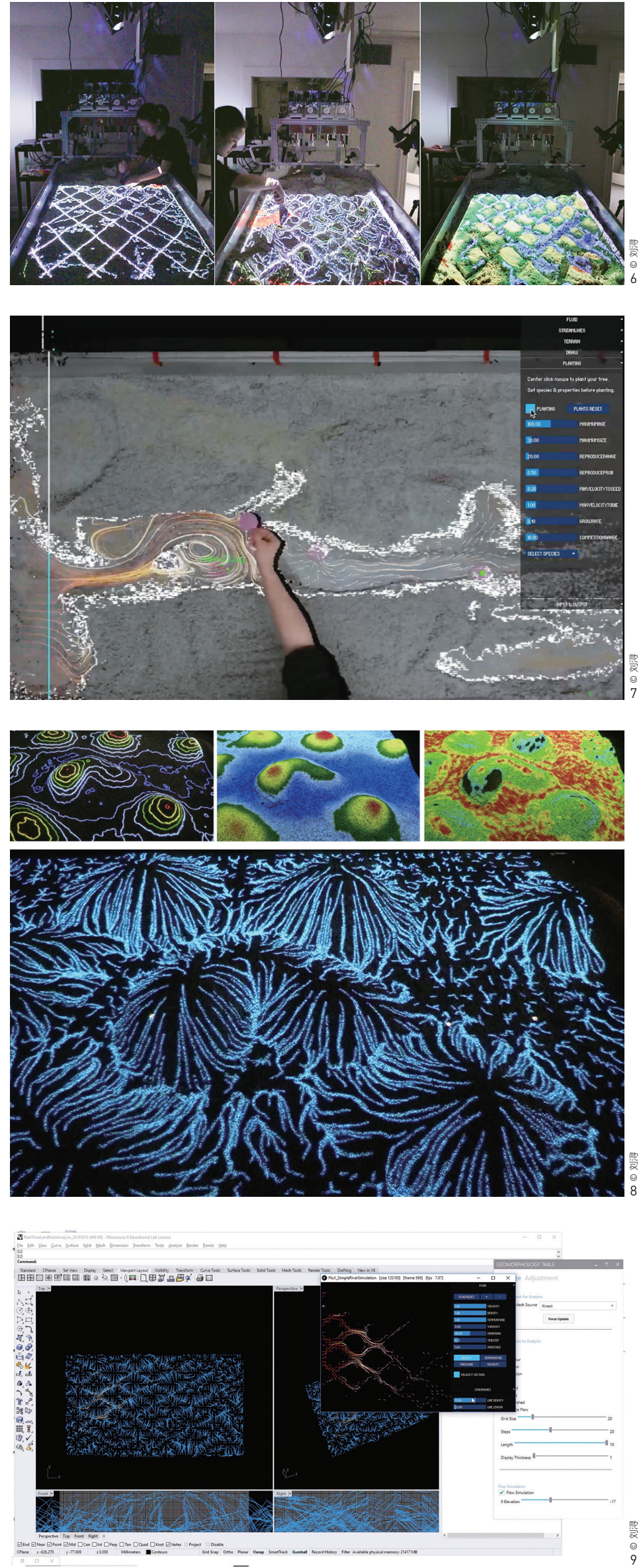

informed by computational simulation results. The dynamics and indeterminacy of the tangible model are important in terms of understanding the complexity and dynamic process of the hydro-morphological process. This prototype acts as a dynamic interface between designers and the physical world.

Particularly, this hydromorphology table as a prototype is not meant to replicate processes in a site-specific hydrological and ecological system. The presumed scale of the model is not built based on a mathematically scaled relationship with real landscape conditions. In other words, if the table is understood in the means-end relation, it can only exist as a scaled simulation of the real environment so that to predict and determine outcomes of different intervention strategies, like the Mississippi Basin Model or the South Florida Water Management Model. However, the discussion about modelmaking would eventually revolve around the question of how "accurate" the model is to represent the environment; that is, the parameter uncertainty involved in the simulation. In modeling practices, uncertainties come from various sources such as structural uncertainty and algorithmic uncertainty. Parameter uncertainty comes from the variability of input variables of the model. In the case of the hydromorphology table, the designer can change the composition of the "sediment" by adjusting the size of each material and the percentage of that material in the sediment mixture. The designer can also vary the flow of water in terms of speed and quantity. These are all implicit variables involved in the model itself, and changing any of them could easily alter the outcome of the simulation. If the table is treated as a predictive model, then the designer is challenged to minimize parameter uncertainties by figuring out the values of all the parameters in the modeling process. The designer has to select not only the correct size of the material to emulate the sediment on-site but also the composition of the material that best represents the sediment. Not to mention that the designer has to calculate the underlying physics involved in the scaling process itself, since everything but water is scaled down; and to counter this issue, the designer might have to switch to another type of fluid with the right viscosity that best represents the interaction between the fluid and the solid particles to scale. These examples only provide a glimpse of the line of reasoning that one inevitably takes if one follows the means-end equation and understands the hydromorphology table as a model of an ideal form to reconstruct the reality. In such conceptualization, uncertainty always exists. Most importantly, following the meansend equation, the discussion drifted away from the design practice and creativity. However, if designers understand the 
下的讨论偏离了设计和创造性。然而, 如果将沙床理解为一种原型, 将它视作一个自成体系的环境，一种自主的、不断演化的系统，设计 师就能探索更多的设计可能性（如响应式框架），从而避免陷人控制 和不确定性的无解争取, 景观的未来才能拥有更多的机遇。

\section{4 结论与讨论}

控制论运动和景观设计的比照揭示了自 20 世纪60年代以来的现代 景观设计发展历程反映着控制论的三次思潮。不确定性概念起初被理 解为模型与环境间必须要被消除的差异, 而后来则被视为演生与机遇 的来源。在演生论的框架下, 原型被解读为一种特殊的模型, 将其与 预测性模型进行对比，会发现二者对于不确定性有着截然不同的理解 思路。利用预测性模型思考问题，会不由自主地通过手段一目的链来 理解不确定性，环境也因此被简化成了一种理想化模型，任何的行为 都必须具有目的性，必须通过手段来实现一个最终目标。不同于预测 性模型所追求的生命系统, 原型本身就是一个独立自主的生命系统, 不存在与现实环境的差异, 因为原型正是环境的一部分。用原型思维 取代建模思维后，不确定性也具有了新的含义一一更多的机会与期 待。在原型思维范式中, 不确定性将激发演生行为, 以及无限的可能 性（图10）。

原型思维范式具有如下三个特点。首先, 原型最初可能只用于测 试某一原理或想法，但一旦被制造出来，便会成为现实的一部分，从 而引发新一轮的观察与建模。这种迭代过程是设计和创造力的基础。

其次，尽管原型可直接用于某些场景，但其真正的用途恰恰在于其未 被限定用途—— “蛾”、沙床等原型甚至没有专业名称一一但正由于 不确定性，原型才具有无限的潜力。最后，这种无定义的状态，以及 原型所具有的不确定性和无限潜能将改变人们与未来之间的关系。LAF hydromorphology table as a prototype, then their relationship with the future is in the line of emergence and opportunity. By regarding this model as its own environment, with its own autonomous and evolving processes, designers can explore a wide range of possibilities of intervention, such as the responsive framework, thus bypassing the discussion about control and uncertainty.

\section{Conclusion and Discussion}

Contrasting the cybernetics movement with landscape design reveals that the development in landscape discourse since the 1960s mirrors the movement of cybernetics.

Uncertainty has transformed from the early understanding that the disconnection between the model and the environment has to be reduced to a contemporary understanding that uncertainty can be the source of emergence and opportunity. The framework of emergence highlights prototypes as a special type of model. Prototypes can be contrasted with predictive models as they entail two different lines of reasoning around the issue of uncertainty. With predictive models, we are forced to understand uncertainty within a means-end relationship that reduces the environment to a simplified representation or ideal image, and then make it a goal and an end, which calls for means to achieve it. Rather than predictive models that represent another living system, prototypes are living systems in themselves with autonomy and lives, and no longer entail a model-environment difference because they are part of the environment. Prototyping replaces model-making and helps establish a new relationship with uncertainty in the line of opportunity and anticipation. Uncertainty in the paradigm of prototyping can be understood as the source for emergent behaviors and a wide range of possibilities (Fig. 10).

There are three characteristics of the paradigm of prototyping. First, prototypes might start as a test of a principle or an idea, but when they are built, they take on a life of their own and become part of reality that triggers new rounds of observation and model-making. This iterative process is the basis for design and creativity. Second, prototypes may have some direct applications, but their true application lies in their undefined identity. "The moth" did not even have a proper name, and neither did the hydromorphology table. However, just because of this undefined identity, a prototype has the potential to become anything. Third, because of this undefined quality of prototypes, they are full of uncertainty, thus infinite possibility, and our relationship with the future has changed. LAF 
10. The relationship between predictive modeling an prototyping

\section{REFERENCES}

[1] Spirn, A. W. (1995). Constructing Nature: The Legacy of Frederick Law Olmsted. In W. Cronon [Ed J, Uncommon Ground: Toward Reinventing Nature (pp. 91-113) New York: W.W. Norton and Company

[2] Prototype. (2000). In Oxford English Dictionary. Oxford: Oxford University Press.

[3] Jullien, F. (2004). A Treatise on Efficacy: Between Western and Chinese Thinking (J. Lloyd, Tran.). Honolulu: University of Hawaii Press.

[4] Sadler, J. M., Goodall, J. L., Behl, M., Bowes, B. D., \& Morsy, M. M. (2020). Exploring real-time control of stormwater systems for mitigating flood risk due to sea level rise. Journat of Hydrology (583), 124571. https //d org/10.1016/j.jhydrol.2020.124571

[5] Fung, S. (1999). Mutuality and the Cultures of Landscape Architecture. In J. Corner (Ed.), Recovering landscape: Essays in contemporary landscape theory (pp. 141-15). Hudson: Princeton Architectural Press.

[6] Herrington, S. (2016). Landscape Theory in Design. London: Routledge.

[7] Lystra, M. (2014). McHarg's Entropy, Halprin's Chance: Representations of Cybernetic Change in 1960s Landscape Representalions of Cybernetic Change in 1960 Lar Designed Landscapes, 34111. 71-84. https://doi.org/10.1080 Designed Landscapes, 3411

B] Hayles, N. K. (1999). How We Became Posthuman: Virtual Bodies in Cybernetics, Literature, and Informatics. Chicago: University of Chicago Press.

[9] Maturana, H. R., \& Varela, F. J. (1980). Autopoiesis and
Cognition: The Realization of the Living. Heidelberg: Springer Netherlands. https://doi.org/10.1007/978-94009-8947-4

[10] Steiner, F. R. (2008). The Ghost of lan McHarg. Log, (13/14) 147-151

[11] OMA Office Work Research. (n.d.). Parc de la Villette. Retrieved from https://oma.eu/projects/parc-de-la-villett

[12] OMA Office Work Research. (n.d.). The Downsview Park competition. Retrieved from https://oma.eu/projects/ downsview-park

[13] Czerniak, J. (2001). Downsview Park Toronto. New York: Prestel.

[14] Hill, K. (2001). Urban Ecologies: Biodiversity and Urban Design. In J. Czerniak (Ed.), Downsview Park Toronto (pp. 90-1011. New York: Prestel.

[15] Reed, C., \& Lister, N. M. (2014). Ecology and Design: Parallel Genealogies. Places Journal. Retrieved from https://placesjournal.org/article/ecology-and-designparallel-genealogies/

[16] Berrizbeitia, A. (2001). Scale of Undecidability. In J. Czerniak (Ed.), Downsview Park Toronto (pp. 117-125). New York: Prestel.

[17] Wiener. N. (1950). The Human Use of Human Beings: Cybernetics and Society. Boston: Houghton Mifflin.

[18] Star, S. L., \& Griesemer, J. R. (2016). Institutional Ecology, 'Translations' and Boundary Objects: Amateurs and Professionals in Berkeley's Museum of Vertebrate Zoology. 1907-39. Social Studies of Science, 19(1989), 387-420.

[19] Von Neumann, J., \& Burks, A. W. (1966). Theory of Self-
Reproducing Automata. Urbana: University of Illinois Press 20] Ray, T. S. (n.d.). Tierra. Retrieved from https://web.stanford edu/class/sts129/Alife/html/Tierra htm

21] Cheramie, K. (2011). The Scale of Nature: Modeling the Mississippi River. Retrieved from https://placesjournal.org/ article/the-scale-of-nature-modeling-the-mississippi-river/

[22] South Florida Water Management District. In.d.). South Florida Water Management Model (SFWMM). Retrieved from https://www.sfwmd.gov/science-data/sfwmm-model

[23] Cantrell, B., Martin, L. J., \& Ellis, E. C. (2017). Designing Autonomy: Opportunities for New Wildness in the Anthropocene. Trends in Ecology and Evolution, 32(3), 156 166. https://doi.org/10.1016/j.tree.2016.12.004

[24] Cantrell, B, \& Holtzman J (2016). Responsive landscapes: Strategies for responsive technologies in landscape architecture. New York: Routledge.

[25] Estrada, L. (2018). Towards Sentience. In B. Cantrell \& A. Mekies (Eds.), Codify: Parametric and Computational Design in Landscape Architecture (pp. 279-288). New York: Routledge.

[26] Liu, X. (2020). The Third Simulation: Augmented Reality Fluvia Modeling Tool. Journal of Digital Landscape Architecture, (5), 413-421. https://doi.org/doi:10.14627/537690042

[27] Ishii, H. \& Ullmer, B. [1997]. Tangible Bits: Towards Seamless Interfaces between People, Bits and Atoms. In Proceedings of the SIGCHI Conference on Human Factors in Computing Systems (pp. 234-241). Retrieve from: http://ebusiness.mit. edu/sponsors/common/LnchSemExecSum/ishii.pdf 